\title{
GAMBARAN GEJALA KLINIS DAN HASIL PEMERIKSAAN CT SCAN KEPALA PADA PASIEN CEDERA KEPALA DENGAN GCS 13-15 DI RUANG RAWAT INAP PENYAKIT SARAF BOUGENVIL RSUD DR. H. ABDUL MOELOEK PROVINSI LAMPUNG
}

\author{
Sandhy Arya Pratama ${ }^{1}$ \\ ${ }^{1}$ Departemen Histologi, Fakultas Kedokteran, Universitas Malahayati
}

\begin{abstract}
Clinical Symptoms and CT Head Scan Examination Results In Head Injury Patients with GCS 13-15 In The Hospital Of Bougenvil Nerve Disease In RSUD Dr. H. Abdul Moeloek Lampung Province. Head injury is one of the leading causes of death among productive ages between 15-44 years. Computed Tomography Scan (CT Scan) The head has an indication for moderate to severe head injuries, whereas a mild head injury is needed only for certain indications. 6 The study was conducted to determine the clinical symptoms and the results of a CT scan of the head in head injuries with GCS (Glasgow Coma Scale ) 13-15. This research is a type of observational descriptive study with a retrospective study approach.26 This study involved 99 samples of determined patients who came for treatment and were treated in the Bougenvil Neurological Disease Inpatient Hospital Dr. H. Abdul Moeloek Lampung Province. Data were analyzed and interpreted by univariate analysis. The results showed that most head injury sufferers with GCS 13-15 based on age were found in the age group of 17-25 years as many as 22 cases $(22.2 \%)$. Most of the male head injury patients were 72 people $(72.7 \%)$. Most of the patients had activities or jobs as students as many as 28 people $(28.3 \%)$. The most common cause of injury from traffic accidents was 85 people $(85.9 \%)$. Most of them have clinical symptoms of headache, which is equal to 81 people. The patient had an abnormal CT scan result of 61 people $(61.6 \%)$. Abnormalities obtained were cranial fractures by 11 people $(11.1 \%)$, SDH by 10 people $(10.1 \%)$, EDH by 6 people $(6.1 \%)$, SAH by 6 people $(6.1 \%)$, Edema cerebri as many as 6 people $(6.1 \%)$, ICH as many as 3 people $(3.0 \%)$.
\end{abstract}

Keywords : Head Injury, GCS, CT Scan

\begin{abstract}
Abstrak : Gambaran Gejala Klinis dan Hasil Pemeriksaan CT Scan Kepala Pada Pasien Cedera Kepala dengan GCS 13-15 Di Ruang Rawat Inap Penyakit Saraf Bougenvil RSUD Dr. H. Abdul Moeloek Provinsi Lampung. Cedera kepala adalah salah satu penyebab kematian utama dikalangan usia produktif antara 15-44 tahun. Computed Tomography Scan (CT Scan) Kepala mempunyai indikasi untuk cidera kepala sedang sampai berat, sedangkan cedera kepala ringan diperlukan hanya untuk indikasi tertentu. ${ }^{6}$ Penelitian dilakukan untuk mengetahui gambaran gejala klinis dan hasil pemeriksaan CT Scan kepala pada cedera kepala dengan GCS (Glasgow Coma Scale) 13-15. Penelitian ini merupakan jenis penelitian deskriptif observasional dengan pendekatan studi retrospektif. ${ }^{26}$ Penelitian ini melibatkan 99 sampel pasien yang ditentukan yang datang berobat dan dirawat di Ruang Rawat Inap Penyakit Saraf Bougenvil RSUD Dr. H. Abdul Moeloek Provinsi Lampung. Data dianalisis dan di interpretasikan dengan analisis univariat. Hasil penelitian menunjukkan penderita cedera kepala dengan GCS 13-15 terbanyak berdasarkan Umur dijumpai pada kelompok umur 17-25 tahun sebanyak 22 kasus $(22,2 \%)$. Sebagian besar pasien cedera kepala berjenis kelamin Laki-laki yaitu sebanyak 72 orang $(72,7 \%)$. Sebagian besar pasien memiliki aktivitas atau pekerjaan sebagai pelajar sebanyak 28 orang $(28,3 \%)$. Penyebab cedera terbanyak dari kecelakaan lalu lintas sebanyak 85 orang $(85,9 \%)$. Sebagian besar memiliki
\end{abstract}


gejala klinis sakit kepala yaitu sebanyak sebesar 81 orang. Pasien memiliki hasil pemeriksaan CT Scan kepala abnormal yaitu sebesar 61 orang $(61,6 \%)$. Kelainan yang didapat yaitu fraktur kranial sebanyak 11 orang $(11,1 \%)$, SDH sebanyak 10 orang $(10,1 \%)$, EDH sebanyak 6 orang $(6,1 \%)$, SAH sebanyak 6 orang $(6,1 \%)$, Edema serebri sebanyak 6 orang $(6,1 \%)$, ICH sebanyak 3 orang $(3,0 \%)$.

Kata kunci : Cedera Kepala, GCS, CT Scan

\section{PENDAHULUAN}

Cedera kepala merupakan salah satu masalah kesehatan yang dapat menyebabkan gangguan fisik dan mental yang kompleks. Cedera kepala adalah salah satu penyebab kematian utama dikalangan usia produktif antara 15-44 tahun. Secara global insiden cedera kepala meningkat dengan tajam terutama karena peningkatan penggunaan kendaraan bermotor. WHO (World Health Organization) memperkirakan bahwa pada tahun 2020, kecelakaan lalu lintas akan menjadi penyebab penyakit dan trauma ketiga terbanyak di dunia (Nurfaise, 2012).

Laporan Hasil Riset Kesehatan Dasar (RISKESDAS) Provinsi Lampung Kementerian Republik Indonesia tahun 2007, bahwa dari 10 kabupaten di provinsi Lampung, prevalensi tertinggi terdapat pada kota Bandar Lampung $6,3 \%$, sedangkan yang terendah terdapat pada kabupaten Way Kanan $1,8 \%$. Sementara untuk urutan penyebab cedera yaitu jatuh, kecelakaan transportasi darat, dan terluka benda tajam/tumpul. Persentase tertinggi bagian tubuh yang terkena cedera kepala berdasarkan kabupaten di provinsi Lampung terbanyak adalah kabupaten Way Kanan. Persentase tertinggi bagian tubuh yang terkena cedera kepala berdasarkan kelompok umur di provinsi Lampung adalah $26,5 \%$ ditemukan pada pada anak kurang satu tahun, 514 tahun, 25-34 tahun, 45-54 tahun, dan umur 65-74 tahun. Penduduk yang mempunyai angka tertinggi terjadinya cedera kepala adalah penduduk yang tamat SMP. Persentase tertinggi bagian cedera kepala menurut jenis kelamin adalah laki-laki (Balitbangkes, 20098.

Cedera kepala merupakan salah satu penyebab utama rawat inap di bangsal Neurologi dan Pasien dengan Glasgow Coma Scale (GCS) skor 13-15 adalah kasus yang paling umum ditemukan dalam keadaan darurat dan neurologi. Hasil penelitian yang dilakukan Turana dan Janis di Rumah Sakit Cipto Mangunkusumo antara tahun 1998-2000, menunjukkan bahwa $44 \%$ dari pasien dengan perdarahan intrakranial memiliki skor 13-15 pada GCS. Persentase yang tinggi ini menunjukkan bahwa tanda-tanda / gejala yang ditemukan pada pasien trauma kepala harus dipertimbangkan untuk mengindentifikasi kelainan. Penggunaan CT Scan kepala pada pasien cedera kepala ringan (CKR), saat ini masih menjadi kontroversial (Jannis, 2004).

Pada hasil penelitian Miranda Esther Irene Manarisip, tentang Gambaran CT Scan Kepala Pada Penderita Cedera Kepala Ringan Di Instalasi Gawat Darurat Bedah Prof. Dr. R. D. Kandou Manado Periode 20122013. Pasien cedera kepala ringan yang paling banyak adalah laki-laki sebanyak $76 \%$ dengan kelompok umur terbanyak > 15-20 tahun sebanyak $26 \%$. Penyebab cedera kepala ringan memiliki hasil CT Scan dengan gambaran yang normal, sedangkan gambaran CT Scan abnormal yang paling banyak adalah intracranial haemorrhage (ICH) sebanyak 34\% (Esther, 2014).

Hasil Penelitian Landong Sijabat tentang Karakteristik Klinis Cedera Kepala Berdasarkan Tingkat Keparahannya Pada Pasien Di Ruang Rawat Inap RSUD Dr. H. Abdul Moeloek Periode Januari Hingga Desember 2010, data menunjukkan bahwa pasien cedera kepala terbanyak terdapat pada usia 16-30 tahun sebanyak 46,67\%, jenis kelamin terbanyak adalah laki-laki yaitu $86,67 \%$. Nyeri kepala pada CKR 
sebanyak $80 \%$. Kehilangan kesadaran pada CKR sebanyak 50\%. Pupil isokor pada CKR sebanyak 100\%(Sijabat, 2014).

Berdasarkan latar belakang di atas, maka dilakukan penelitian untuk mengetahui bagaimana gambaran

\section{METODE PENELITIAN}

Penelitian ini merupakan jenis penelitian deskriptif observasional tanpa perlakuan dengan menggunakan pendekatan studi retrospektif (Notoatmodjo, 2012). Suatu metode penelitian yang dilakukan dengan menganalisis catatan medik pada penderita cedera kepala dengan GCS 13-15. Tempat pada penelitian ini adalah di Ruang Rawat Inap Penyakit Saraf Bougenvil RSUD Dr. H. Abdul Moeloek Provinsi Lampung. Sampel dalam penelitian ini adalah 99 pasien ditentukan yang datang berobat dan dirawat di Ruang Rawat Inap Penyakit Saraf Bougenvil RSUD Dr. H. Abdul Moeloek Provinsi Lampung dengan kriteria tertentu. Kriteria pasien terserut yaitu 1) Pasien yang mengalami cedera kepala di Ruang Rawat Inap Penyakit Saraf Bougenvil RSUD Dr. H. Abdul Moeloek Provinsi Lampung pada bulan Januari-

\section{HASIL}

Berdasarkan tabel 1 di bawah, diketahui bahwa sebagian besar pasien cedera kepala dengan GCS 13-15 di Ruang Bougenvil Penyakit Saraf RSUD DR. H. Abdul Moeloek Provinsi Lampung tahun 2014 berusia 17-25 tahun yaitu sebanyak 22 orang $(22,2 \%)$. Berdasarkan tabel 2 di bawah, diketahui bahwa sebagaian besar pasien cedera kepala dengan GCS 13-15 Di Ruang Bougenvil Penyakit Saraf RSUD DR. H. Abdul Moeloek Provinsi Lampung tahun 2014 berjenis kelamin Laki-laki yaitu sebanyak 72 orang $(72,7 \%)$. Berdasarkan tabel 3 di bawah, diketahui bahwa sebagian besar Pasien gejala klinis dan hasil pemeriksaan CT Scan kepala pada cedera kepala dengan GCS (Glasgow Coma Scale) 1315 di Ruang Rawat Inap Penyakit Saraf Bougenvil RSUD Dr. H. Abdul Moeloek Provinsi Lampung.

September 2014. 2) Pasien yang terdiagnosa oleh dokter mengalami cedera kepala dengan GCS 13-15. 3) Pasien yang telah melakukan pemeriksaan CT Scan kepala.

Data dianalisis dan di interpretasikan dengan menguji hipotesis menggunakan program komputer SPSS 20.0 for windows. Analisis univariat bertujuan untuk menjelaskan atau mendeskripsikan karakteristik setiap variabel penelitian. Bentuk analisis univariat tergantung dari jenis datanya. Untuk data numerik digunakan nilai mean atau rata-rata, median dan standar deviasi. Pada umumnya dalam analisis ini hanya menghasilkan distribusi frekuensi dan persentase dari setiap variabel (Notoatmodjo, 2012).

cedera kepala dengan GCS 13-15, data tidak diketahui sebesar 47 orang $(47,5 \%)$ dikarenakan data tidak dicantumkan di rekam medik. Namun sebagian data dapat teridentifikasi, Pasien cedera kepala dengan GCS 1315 memiliki aktifitas sebagai Pelajar terbanyak dengan 28 orang (28,3\%). Berdasarkan tabel 4 di bawah, diketahui bahwa sebagaian besar pasien cedera kepala dengan GCS 1315 di Ruang Bougenvil Penyakit Saraf RSUD DR. H. Abdul Moeloek Provinsi Lampung 2014 terjadi kecelakaan lalu lintas yaitu sebanyak sebesar 85 orang $(85,9 \%)$. 
Tabel 1. Gambaran Umur Pasien cedera kepala dengan GCS 13-15 Di Ruang Bougenvil Penyakit Saraf RSUD DR. H. Abdul Moeloek Provinsi Lampung 2014.

\begin{tabular}{ccc}
\hline Umur & Frekuensi & Persentase (\%) \\
\hline $12-16$ & 15 & 15,2 \\
\hline $17-25$ & 22 & 22,2 \\
\hline $26-35$ & 20 & 20,2 \\
\hline $36-45$ & 21 & 21,2 \\
\hline $46-55$ & 14 & 14,1 \\
\hline $56-65$ & 3 & 3,0 \\
\hline$>65$ & 4 & 4,0 \\
\hline Jumlah & $\mathbf{9 9}$ & $\mathbf{1 0 0}$ \\
\hline
\end{tabular}

Tabel 2. Gambaran Jenis Kelamin Pasien cedera kepala dengan GCS 13-15 Di Ruang Bougenvil Penyakit Saraf RSUD DR. H. Abdul Moeloek Provinsi Lampung 2014.

\begin{tabular}{lcc}
\hline $\begin{array}{c}\text { Jenis } \\
\text { Kelamin }\end{array}$ & Frekuensi & Persentase (\%) \\
\hline Laki-laki & 72 & 72,7 \\
\hline Perempuan & 27 & 27,3 \\
\hline Jumlah & $\mathbf{9 9}$ & $\mathbf{1 0 0 , 0}$ \\
\hline
\end{tabular}

Tabel 3. Gambaran Pekerjaan Pasien cedera kepala dengan GCS 13-15 Di Ruang Bougenvil Penyakit Saraf RSUD DR. H. Abdul Moeloek Provinsi Lampung 2014.

\begin{tabular}{lcc}
\hline \multicolumn{1}{c}{ Pekerjaan } & Frekuensi & Persentase (\%) \\
\hline Tidak Ada & 47 & 47,5 \\
\hline PNS & 3 & 3,0 \\
\hline Pelajar & 28 & 28,3 \\
\hline Buruh & 2 & 2,0 \\
\hline Pegawai Swasta & 6 & 6,1 \\
\hline Wiraswasta & 4 & 4,0 \\
\hline Petani & 5 & 5,1 \\
\hline IRT & 4 & 4,0 \\
\hline Jumlah & $\mathbf{9 9}$ & $\mathbf{1 0 0}$ \\
\hline
\end{tabular}

Tabel 4. Gambaran penyebab cedera kepala dengan GCS 13-15 Di Ruang Bougenvil Penyakit Saraf RSUD DR. H. Abdul Moeloek Provinsi Lampung 2014.

\begin{tabular}{lcc}
\hline \multicolumn{1}{c}{ Penyebab } & Frekuensi & Persentase (\%) \\
\hline Kecelakaan lalu lintas & 85 & 85,9 \\
\hline Jatuh & 11 & 11,1 \\
\hline Trauma benda tumpul & 3 & 3,0 \\
\hline Jumlah & $\mathbf{9 9}$ & $\mathbf{1 0 0}$ \\
\hline
\end{tabular}


Berdasarkan tabel 5 di bawah, diketahui bahwa sebagian besar pasien cedera kepala dengan GCS 13-15 di Ruang Bougenvil Penyakit Saraf RSUD DR. H. Abdul Moeloek Provinsi Lampung 2014 memiliki gejala klinis sakit kepala yaitu sebanyak sebesar 81 orang. Berdasarkan tabel 6 di bawah, diketahui bahwa sebagian besar pasien cedera kepala dengan GCS 13-15 di Ruang Bougenvil Penyakit Saraf RSUD DR. H. Abdul Moeloek Provinsi
Lampung 2014 memiliki hasil pemeriksaan CT Scan kepala Abnormal yaitu sebesar 61 orang $(61,6 \%)$. Berdasarkan tabel 7 di bawah, diketahui bahwa sebagaian besar pasien cedera kepala dengan GCS 1315 di Ruang Bougenvil Penyakit Saraf RSUD DR. H. Abdul Moeloek Provinsi Lampung 2014 memiliki hasil pemeriksaan CT Scan kepala abnormal terbanyak yaitu fraktur kranial sebesar 11 pasien $(11,1 \%)$.

Tabel 5. Gambaran Gejala Klinis Cedera Kepala Dengan GCS 13-15 Di Ruang Bougenvil Penyakit Saraf RSUD DR. H. Abdul Moeloek Provinsi Lampung 2014.

\begin{tabular}{lcc}
\hline Gejala Klinis & Frekuensi & Persentase (\%) \\
\hline Sakit kepala & 81 & \\
\hline Mual & 24 \\
\hline Muntah & 55 & \\
\hline Amnesia retrograde & 16 \\
\hline Pingsan saat kejadian & 70 \\
\hline Otorea & 21 \\
\hline Rinorea & 20 \\
\hline Battle sign & 1 & \\
\hline Racoon eyes & 3 & \\
\hline Jumlah & $\mathbf{9 9}$ & $\mathbf{1 0 0}$ \\
\hline
\end{tabular}

Tabel 6. Gambaran Hasil Pemeriksaan CT Scan Cedera Kepala Dengan GCS 13-15 Di Ruang Bougenvil Penyakit Saraf RSUD DR. H. Abdul Moeloek Provinsi Lampung 2014.

\begin{tabular}{lcc}
\hline Hasil CT Scan & Frekuensi & Persentase (\%) \\
\hline Normal & 38 & 38,4 \\
\hline Abnormal & 61 & 61,6 \\
\hline Jumlah & $\mathbf{9 9}$ & $\mathbf{1 0 0 , 0}$ \\
\hline
\end{tabular}

Tabel 7. Gambaran Hasil Pemeriksaan CT Scan Cedera Kepala Abnormal Dengan GCS 13-15 Di Ruang Bougenvil Penyakit Saraf RSUD DR. H. Abdul Moeloek Provinsi Lampung 2014.

\begin{tabular}{lll}
\hline Hasil Pemeriksaan CT Scan & Frekuensi & Persentase \\
\hline Normal & 38 & 38,4 \\
\hline Edema Cerebri & 6 & 6,1 \\
\hline ICH & 3 & 3,0 \\
\hline EDH & 6 & 6,1 \\
\hline SDH & 10 & 10,1 \\
\hline SAH & 6 & 6,1 \\
\hline Fraktur kranial & 11 & 11,1 \\
\hline EDH + SDH & 3 & 3.0 \\
\hline Fraktur kranial + EDH + SDH + ICH & 1 & 1.0 \\
\hline Hogroma Subdural & 2 & 2.0 \\
\hline
\end{tabular}




\begin{tabular}{lll}
\hline EDH + ICH + Edema serebri & 1 & 1,0 \\
\hline ICH + SDH & 1 & 1,0 \\
\hline Fraktur kranial + SDH & 1 & 1,0 \\
\hline Fraktur kranial + ICH & 2 & 2,0 \\
\hline Fraktur kranial + ICH + SAH & 1 & 1,0 \\
\hline Fraktur kranial + ICH + EDH & 1 & 1,0 \\
\hline Edema serebri + EDH + SDH & 1 & 1,0 \\
\hline EDH + SAH & 1 & 1,0 \\
\hline ICH + SDH + SAH & 1 & 1,0 \\
\hline Fraktur kranial + Higroma Subdural & 2 & 2,0 \\
\hline $\begin{array}{l}\text { Fraktur kranial + SDH + SAH + Edema } \\
\text { serebri }\end{array}$ & 1 & 1,0 \\
\hline Jumlah & $\mathbf{9 9}$ & $\mathbf{1 0 0}$
\end{tabular}

\section{PEMBAHASAN}

Penelitian ini menunjukkan bahwa distribusi frekuensi penderita cedera kepala dengan GCS 13-15 terbanyak berdasarkan Umur dijumpai pada kelompok umur 17-25 tahun sebanyak 22 kasus (22,2\%), kemudian pada kelompok umur 36-45 tahun sebanyak 21 kasus $(21,2 \%)$, pada kelompok umur 26-35 tahun sebanyak 20 kasus $(20,2 \%)$, pada kelompok 12-16 tahun sebanyak 15 kasus $(15,2 \%)$, pada kelompok umur 46-55 tahun sebanyak 14 kasus $(14,1 \%)$, pada kelompok umur >66 tahun sebanyak 4 kasus $(4,0 \%)$, dan pada kelompok umur 5665 tahun sebanyak 3 kasus (3,0\%).

$$
\text { Penelitian yang dilakukan }
$$

Nurfaise di RSU DR. Soedarso periode Mei-Juli 2012 menyimpulkan bahwa usia cedera kepala termuda adalah lima tahun, sedangkan usia tertua 80 tahun. Kelompok usia pasien cedera kepala tersering adalah kelompok usia 15-60 tahun yaitu sebanyak 82 orang $(81,2 \%)$. Kelompok usia pasien cedera kepala yang paling sedikit yaitu kelompok umur lebih dari 60 tahun sebesar 2\%, sedangkan untuk 5-14 tahun adalah sebanyak 17 pasien (17 pasien (16,8\%) (Nurfaise, 2012).

Pada penelitian Jofizal Jannis di RUP Dr. Cipto Mangunkusumo tahun1999-2001, didapatkan proporsi kelompok umur pasien terbanyak adalah pada kelompok umur 9-29 tahun sebanyak 89 kasus, sedangkan proporsi yang paling sedikit adalah pada kelompok umur $>60$ tahun, yaitu sebanyak 5 kasus (Jannis, 2004). Jurnal Ilmu Kedokteran Dan Kesehatan, Volume 7, Nomor 2, April 2020
Sedangkan penelitian yang dilakukan oleh Ayu Lintang Putri di RSUD DR. Moewardi Surakarta, didapatkan penderita trauma kepala ringan-sedang terbanyak pada kelompok umur 20-30 tahun, yaitu sebanyak 16 sampel atau berkisar $32 \%$ dan paling sedikit pada kelompok umur 41-50 tahun, sebanyak 10 sampel atau berkisar 20\%(Putri, 2014).

Menurut Miranda Esther Irene Manarisip di BLU Prof. Dr. R. D. Kandou Manado Periode 2012-2013, Kelompok umur 15-20 tahun sangat rentan dengan keadaan yang berisiko tinggi cedera kepala seperti kecelakaan lalulintas dan perkelahian. Selaian itu, di umur yang masih muda tersebut tingkat kematangan emosional masih belum stabil sehingga mudah terlibat dalam keadaan yang berisiko mengalami cedera kepala (Miranda, 2014).

Berdasarkan hasil penelitian, diketahui bahwa sebagian besar pasien cedera kepala dengan GCS 13-15 di Ruang Bougenvil Penyakit Saraf RSUD DR. H. Abdul Moeloek Privinsi Lampung tahun 2014 berjenis kelamin Laki-laki yaitu sebanyak 72 orang $(72,7 \%)$. Penelitian ini sesuai dengan penelitian Nurfaise di RSU DR. Soedarso Periode Mei-Juli 2012, terdapat jenis kelamin cedera kepala yang terdata pada penilitian ini sebagian besar adalah laki-laki, yaitu sebanyak 74 pasien $(73,3 \%)$, sedangkan perempuan adalah sebanyak 27 pasien $(26,7 \%)$ (Nurfaise, 2012). Pada penelitian Miranda Esther Irene Manarisip di BLU
7, Nomor 2, April 2020 
Prof. Dr. R. D. Kandou Manado Periode 2012-2013, menggambarkan penderita cedera kepala ringanterbanyak adalah laki-laki sebanyak 68 orang, sedangkan perempuan berjumlah 21 orang (24\%). $\mathrm{Hal}$ ini dikarenakan laki-laki lebih sering berada dalam keadaan yang berbahaya seperti mengendarai kendaraan bermotor, perkelahian, buruh bangunan, bahkan berada di tempat-tempat tinggi untuk memperbaiki sesuatu. Sedangkan pada umumnya berada di lingkungan yang aman dan jauh dari risiko cedera kepala (Miranda, 2014).

Berdasarkan hasil penelitian diketahui bahwa sebagian besar pasien cedera kepala dengan GCS 13-15 di Ruang Bougenvil Penyakit Saraf RSUD DR. H. Abdul Moeloek Privinsi Lampung tahun 2014 memiliki aktivitas atau pekerjaan sebagai pelajar sebanyak 28 orang $(28,3 \%)$. Walaupun banyak juga data di rekam medik yang tidak menyertakan datanya. Penelitian ini berbeda dengan Laporan Provinsi Lampung : Riset Kesehatan Dasar (RISKEDAS) tahun 2007, dapat dilihat bahwa persentase cedera kepala menurut jenis pekerjaan, lebih banyak terjadi pada kelompok Pegawai ( Negeri, Swasta, POLRI) yaitu sebesar $17,1 \%$, selanjutnya diikuti pada kelompok Sekolah atau Pelajar sebesar $10.5 \%$ terdapat diurutan kedua (Balitbangkes, 2009).

Penelitian juga berbeda ini dengan Laporan Nasional : Riset Kesehatan Dasar (RISKEDAS) tahun 2007, terdapat persentase cedera kepala menurut jenis pekerjaan, lebih banyak terjadi pada kelompok yang tidak tercamtum jenis pekerjaannya yaitu $13,6 \%$, diurutan kedua terjadi pada kelompok yang tidak bekerja dan wiraswasta yaitu sebesar 12,9\%. Sedangkan pada urutan terendah terjadi pada kelompok Sekolah yaitu sebesar 10,2\% (Balitbangkes, 2008). Hal ini dikarenakan memiliki kesamaan dalam aktivitas yang tinggi yang cenderung berisiko mengalami cedera dan sering berada dalam keadaan yang berbahaya seperti mengendarai motor (Miranda, 2014).
Berdasarkan hasil penelitian, diketahui bahwa sebagian besar pasien cedera kepala dengan GCS 13-15 di Ruang Bougenvil Penyakit Saraf RSUD DR. H. Abdul Moeloek Privinsi Lampung tahun 2014 memiliki penyebab kecelakaan lalu lintas sebanyak 85 orang $(85,9 \%)$.

Penelitian yang dilakukan oleh Nurfaise, terdapat mekanisme utama penyebab cedera kepala adalah kecelakaan lalulintas yaitu sebanyak 46 kasus, sedangkan yang paling sedikit adalah akibat tindak kekerasan yaitu 1 $\%$ (Nurfaise, 2012). Pada penelitian Miranda Esther Irene Manarisip di BLU Prof. Dr. R. D. Kandou Manado Periode 2012-2013, penyebab terjadinya cedera kepala ringan yang paling adalah kecelakaan lalu lintas dengan jumlah 65 kasus (73\%). Kecelakaaan lalulintas dapat mengakibatkan berbagai cedera. Cedera yang paling banyak terjadi pada saat kecelakaan lalu lintas adalah cedera kepala. Cedera kepala akibat kecelakaan lalu lintas merupakan penyebab utama disabilitas dan mortalitas di negara berkembang. Keadaan ini umumnya terjadi pada pengumudi motor tanpa mengenakan helm atau memakai hel yang kurang tepat dan yang tidak memenuhi standar (Miranda, 2014).

Berdasarkan hasil penelitian, diketahui bahwa sebagaian besar pasien cedera kepala dengan GCS 1315 di Ruang Bougenvil Penyakit Saraf RSUD DR. H. Abdul Moeloek Provinsi Lampung 2014 terletak di Bandar Lampung yaitu sebanyak sebesar 45 orang $(45,5 \%)$. Terdapat kesamaan hasil dari Laporan Provinsi Lampung : Riset Kesehatan Dasar (RISKEDAS) tahun 2007amemberikan gambaran bahwa di Provinsi Lampung, prevalensi tertinggi terdapat pada kota Bandar Lampung $6,3 \%$, sedangkan yang terendah terdapat pada kabupaten Way kanan 1,8\% (Balitbangkes, 2009).

Berdasarkan hasil penelitian, diketahui bahwa sebagaian besar pasien cedera kepala dengan GCS 1315 di Ruang Bougenvil Penyakit Saraf RSUD DR. H. Abdul Moeloek Provinsi Lampung 2014 memiliki gejala klinis 
sakit kepala yaitu sebanyak sebesar 81 orang. Selanjutnya diikuti oleh pingsan saat kejadian sebanyak 70 orang, muntah sebanyak 55 orang, mual sebanyak 24 orang, otorea sebanyak 21 orang, rinorea sebanyak 20 orang, amnesia retrograde sebanyak 16 orang, racoon eyes sebanyak 3 orang, dan battle sign sebanyak 1 orang sebanyak.

Cedera Kepala ringan ditandai oleh pasien sadar penuh dan dapat berbicara namun dengan riwayat disorientasi, amnesia atau kehilangan kesadaran sesaat dengan skor GCS antara 13-15. Definsi cedera otak ringan sering dibedakan dari istilah "concussion" yang telah dikenal luas sebagai suatu proses patofisiologis kompleks yang mempengaruhi otak sebagai akibat daya biomekanik cedera. Riwayat kehilangan kesadaran sangat sulit dikonfirmasikan, dan gambarannya sering ditutupi oleh alkohol ataupun keracunan zat lainnya (IKABI, 2008).

Distribusi berdasarkan keluhan pada penderita cedera kepala dengan GCS 13-15 ini tidak jauh berbeda terhadap penelitian yang dilakukan oleh Jofizal Jannis di ruang rawat inap Bagian Neurologi RS DR. Cipto Mangunkusumo tahun 1999-2001. Hasil penelitian diperoleh data bahwa 271 penderita yang menjalani pemeriksaan CT Scan sebagian besar menunjukkan bahwa sakit kepala sebanyak 131 penderita, gangguan saraf otak 19 penderita, amnesia sebanyak 59 penderita, kehilangan kesadaran lebih 10 menit sebanyak 86 penderita, muntah sebanyak 93 penderita, Battle sign sebanyak 21 penderita, dan perdarahan telinga hidung sebanyak 43 penderita (Jannis, 2004). Dapat disimpulkan bahwa dari dua penelitian tersebut memiliki gejala klinis tertinggi yaitu sakit kepala, penurunan kesadaran, dan muntah.

Berdasarkan hasil penelitian, diketahui bahwa sebagian besar pasien cedera kepala dengan GCS 13-15 di Ruang Bougenvil Penyakit Saraf RSUD DR. H. Abdul Moeloek Provinsi Lampung 2014 memiliki hasil pemeriksaan CT Scan kepala yang abnormal yaitu sebesar 61 orang $(61,6 \%)$. Kelainan yang didapat seperti fraktur kranial sebanyak 11 orang $(11,1 \%), \quad$ SDH sebanyak 10 orang $(10,1 \%), \quad \mathrm{EDH}$ sebanyak 6 orang $(6,1 \%)$, SAH sebanyak 6 orang $(6,1 \%)$, Edema serebri sebanyak 6 orang $(6,1 \%), \mathrm{ICH}$ sebanyak 3 orang $(3,0 \%)$, dan seterusnya sesuai Tabel 7 .

Penelitian yang dilakukan oleh Jofizal Jannis di ruang rawat inap Bagian Neurologi RS DR. Cipto Mangunkusumo tahun 1999-2001, dari hasil penelitiannya diperoleh data bahwa dari pasien cedera kepala ringan dengan GCS 13-15 sebanyak 271 penderita yang melakukan pemeriksaan CT Scan. Kelainan CT S can yang ditemukan diantaranya edema serebri $(11,4 \%)$, perdarahan intraparenkhimal $(10,7 \%)$, perdarahan epidural $(16,2 \%)$, perdarahan subdural $(18,1 \%)$, perdarahan subarakhnoid $(5,5 \%)$ dan campuran $(13,8 \%)$ (Jannis, 2004).

Menurut penelitian yang dilakukan oleh Miranda Esther Irene Manarisip di BLU Prof. Dr. R. D. Kandou Manado Periode 2012-2013 , digambarkan bahwa dari 89 kasus yang ada, sebanyak 10 kasus memiliki gambaran CT Scan kepala normal. Dari 79 kasus dengan gambaran CT Scan abnormal, gambaran intracranial haenorrhage (ICH) merupakan yang paling banyak dengan jumlah 30 kasus (34\%). Subarachnoid haemorrhage (SAH) merupakan gambaran yang paling sedikit dengan jumlah 1 kasus (1\%) (Miranda, 2014). Jadi dapat disimpulkan bahwa dari beberapa penelitian sebelumnya, pasien cedera kepala dengan GCS 13-15 yang melakukan pemeriksaan CT Scan memiliki gambaran kelainan yang bervariasi.

\section{KESIMPULAN}

Penderita cedera kepala dengan GCS 13-15 terbanyak berdasarkan Umur dijumpai pada kelompok umur 17-25 tahun sebanyak 22 kasus $(22,2 \%)$. Sebagian besar pasien cedera 
kepala berjenis kelamin Laki-laki yaitu sebanyak 72 orang $(72,7 \%)$. Sebagian besar pasien memiliki aktivitas atau pekerjaan sebagai pelajar sebanyak 28 orang $(28,3 \%)$. Penyebab cedera terbanyak dari kecelakaan lalu lintas sebanyak 85 orang $(85,9 \%)$. Sebagian besar memiliki gejala klinis sakit kepala yaitu sebanyak sebesar 81 orang. Pasien memiliki hasil pemeriksaan CT Scan kepala abnormal yaitu sebesar 61 orang $(61,6 \%)$. Kelainan yang didapat yaitu fraktur kranial sebanyak 11 orang $(11,1 \%), \quad \mathrm{SDH}$ sebanyak 10 orang $(10,1 \%), \quad \mathrm{EDH}$ sebanyak 6 orang $(6,1 \%)$, SAH sebanyak 6 orang $(6,1 \%)$, Edema serebri sebanyak 6 orang $(6,1 \%)$, ICH sebanyak 3 orang $(3,0 \%)$.

\section{DAFTAR PUSTAKA}

Badan Penelitian dan Pengembangan Kesehatan Departemen Kesehatan, Republik Indonesia. (2008). Laporan Nasional : Riset Kesehatan Dasar (RISKEDAS) tahun 2007. Diunduh dari : http ://www.k4health.org. Pada tanggal 10 Februari 2015.

Badan Penelitian dan Pengembangan Kesehatan Departemen Kesehatan, Republik Indonesia. (2009). Laporan Provinsi Lampung : Riset Kesehatan Dasar (RISKEDAS) tahun 2007. Diunduh dari : http ://terbitan.litbang.depkes.go.id. Pada tanggal 10 Februari 2015

Charoliana, D. (2014). Hubungan antara Derajat Cedera Kepala Berdasarkan Glasgow Coma Scale (GCS) dengan Keluhan Nyeri Kepala Pasca Trauma pada Pasien Cedera Kepala di RSUD DR. H. Abdul Moeloek Provinsi Lampung.

Ikatan Ahli Bedah Indonesia. (2008). American College of Surgeons Committee on Trauma. Cedera Kepala dalam Advanced Trauma Life Support for Doctors. Komisi trauma IKABI. Hal 153-177.

Jamaluddin, M. (2008). Karakteristik Kasus Trauma Kepala Di Instalasi Rawat Darurat RSUD Sleman
Periode Maret 2007-Maret 2008. Dari : http ://repository.uii.ac.id, diunduh pada tanggal 13 November 2014.

Jannis, J. (2004). The Use Of Brain CT Scan In Craniocerebral Trauma With Glasdow Coma Scale Of 1315 In Dr. Cipto Mangunkusumo Hospital 1999-2001. Dari : http ://mji.ui.as.id, diunduh pada tanggal 30 November 2014.

Lintang, P. A. (2014). Hubungan Trauma Kepala Ringan sampai Sedang Dengan Vertigo Di RSUD DR. Moewardi Surakarta. Dari : http ://etd.eprints.ums.ac.id, diunduh pada tanggal 13 Desember 2014.

Miranda, E. I. M. (2014). Gambaran CT Scan Kepala Pada Penderita Cedera Kepala Ringan Di BLU Prof. Dr. R. D. Kandou Manado Periode 2012-2013. Dari : http ://download.portalgaruda.org, diunduh pada tanggal 13 November 2014.

Notoatmodjo, S. (2012). Metodologi Penelitian Kesehatan. Edisi Rev. Jakarta : Rineka Cipta.

Nurfaise. (2012). Hubungan Derajat Cidera Kepala Dan Gambaran CT Scan Pada Penderita Cedera Kepala Di RSU DR. Soedarso Periode Mei-Juli 2012. Dari : http ://jurnal.untan.ac.id, diunduh pada tanggal 12 Desember 2014.

Sijabat, L. (2014). Karakteristik Klinis Cedera Kepala Berdasarkan Tingkat Keparahannya Pada Pasien Di Ruang Rawat Inap RSUD Dr. H. Abdul Moeloek Periode Januari Hingga Desember 2010.

Susilawati, D. (2010). Hubungan waktu prehospital dan nilai tekanan darah dengan survival dalam 6 jam pertama pada cedera kepala Berat di IGD RSUP. DR. M. Djamil Padang Tahun 2010. Dari : http ://repository.unand.ac.id, diunduh pada tanggal 13 November 2014. 